\title{
Diabetic ketoalkalosis due to ectopic ACTH production from an oat cell carcinoma
}

\author{
D. W. M. PeARSON* \\ B.Sc., M.R.C.P. \\ A. C. KenNEDY* \\ M.D., F.R.C.P.
}

J. A. THOMSON*

M.D., F.R.C.P.

P. G. TONER $†$

D.Sc., M.R.C.Path.

\author{
J. G. RATCLIFFE $\ddagger$ \\ D.M., M.R.C.Path.
}

\begin{abstract}
University Departments of *Medicine, $\nmid$ Pathology, and $\ddagger$ Pathological Biochemistry, Royal Infirmary, Glasgow G4 OSF
\end{abstract}

\begin{abstract}
Summary
A diabetic patient is described who presented with the bizarre biochemical association of hyperglycaemia, ketosis and severe alkalosis. Investigation revealed hypercortisolaemia due to ectopic adrenocorticotrophic hormone secretion from an oat cell carcinoma of the bronchus and post-mortem studies demonstrated clinically unsuspected resolving pancreatitis. A possible mechanism for the metabolic upset is discussed.
\end{abstract}

\section{Introduction}

Alkalosis is a very unusual feature in diabetic patients with hyperglycaemia and ketosis. Previous reports have detailed how ketoalkalosis in uncontrolled diabetes can result from vomiting (Lim and Walsh, 1976). A case is now reported in whom ectopic adrenocorticotrophic hormone (ACTH) secretion from an oat cell carcinoma of the bronchus produced this unusual biochemical profile. Postmortem examination, in addition to demonstrating the oat cell carcinoma of the bronchus and bilateral adrenal hyperplasia, showed resolving pancreatitis, providing a mechanism to explain the metabolic abnormalities.

\section{Case history}

A 72-year-old widow who had smoked heavily for many years, presented with a 3-month history of general malaise and lethargy, and a 3-week history of polyuria, polydipsia and ankle oedema. There was no history of alkali ingestion or vomiting. She had been treated with a thiazide diuretic and potassium supplementation for one week before admission.

Examination revealed an obese, pigmented, de- hydrated woman with bilateral ankle oedema, bruising of the legs and the smell of acetone from her breath. Urine analysis showed marked ketonuria and glycosuria. Biochemical investigations revealed blood glucose $22.5 \mathrm{mmol} / \mathrm{l}$; serum potassium 1.8 $\mathrm{mmol} / \mathrm{l}$; standard bicarbonate $>40 \mathrm{mmol} / \mathrm{l}$; serum urea $10.5 \mathrm{mmol} / 1 ; \mathrm{pH} 7.61$; base excess $-12 ; \mathrm{Po}_{2}$ $97 \mathrm{mmHg}$ and $\mathrm{PCO}_{2} 34 \mathrm{mmHg}$. Chest X-ray on admission was reported as normal.

The clinical features suggested ectopic ACTH secretion. Serum cortisol was found to be markedly elevated at $2010 \mathrm{nmol} / 1$ (normal range $276 \mathrm{nmol} / 1-$ $690 \mathrm{nmol} / \mathrm{l})$ with a plasma ACTH level of $829 \mathrm{ng} / \mathrm{l}$ (normal range $<80 \mathrm{ng} / \mathrm{l}$ ) and plasma lipotrophin (MSH) level of $5710 \mathrm{ng} / \mathrm{l}$ (normal range $<80 \mathrm{ng} / \mathrm{l}$ ).

Despite rehydration, potassium supplementation, insulin therapy and metyrapone the condition of the patient deteriorated. A repeat chest X-ray revealed an opacity at the right hilum. The patient died 2 weeks following admission and post-mortem studies showed an oat cell carcinoma of the bronchus with metastases involving the hilar lymph nodes, liver, spleen and adrenal medulla. The combined adrenal weight was increased at $18 \mathrm{~g}$ and bilateral diffuse adrenocortical hyperplasia was observed. In addition there was extensive resolving pancreatitis. After death, elevated serum amylase levels ranging from 870-1010 u./l (normal range 70-300 u./l) were measured in the serum specimens taken shortly after admission. Electron microscopic examination of tumour tissue obtained at post-mortem confirmed its epithelial nature by demonstrating quite well formed desmosomes. In addition, small numbers of dense endocrine-type secreting granules were found in the cytoplasm, as described in oat cell carcinoma. 


\section{Discussion}

Detailed review of 68 case reports of adrenal hyperplasia due to a non-pituitary neoplasm revealed diabetic ketoalkalosis associated with a bronchial (Hudson and Evans, 1962), a prostatic (Webstein, Touchstone and Suzuki, 1959) and a tracheal neoplasm (Bornstein, Bernanke and Nolan, 1961). Pancreatitis was present in the patient with the bronchial neoplasm (Hudson and Evans, 1962). The aetiology of the pancreatitis in the present case is not clear. Metastases from a bronchial carcinoma to the pancreas can be associated with inflammatory changes (Yeung et al., 1979) but detailed histology in the present patient failed to reveal pancreatic metastases. The brief course of thiazides could have been responsible but it is felt that the pancreatic changes were probably related to the markedly elevated circulating cortisol levels since pancreatitis is a recognized side effect of high dose steroid therapy.

The combination of insulin deficiency from pancreatitis and gross hypercortisolaemia resulted in the metabolic upset of diabetic ketoalkalosis. Ttee possibility of a bronchial neoplasm or other ACT producing tumour should be considered if this unusual biochemical combination is found.

\section{References}

Bornstein, P., Bernanke, D. \& Nolan, J.P. (1961) Adre cortical hyperfunction in association with anaplasfic carcinoma of the respiratory tract. New England Journa Medicine, 264, 363.

Hudson, B. \& EvaNs, J. (1962) Adrenocortical hyperpla $\overrightarrow{\$}$ associated with bronchogenic carcinoma. Journal $\underline{\partial f}$ Clinical Endocrinology and Metabolism, 22, 494.

Lim, K.C. \& WALSH, C.H. (1976) Diabetic ketoalkalosis 9 readily misdiagnosed entity. British Medical Journal, 19.

Webstein, G.D., Touchstone, J.C., Suzuki, M. (19 Adrenocortical hyperplasia occurring in metastatic disease of the prostate. Journal of Clinical Endocrinology, 19, 9 .

YeunG, K.Y., Haidak, D.J., BRown, J.A. \& ANDERSON, (1979) Metastasis-induced acute pancreatitis in small cell bronchogenic carcinoma. Archives of Internal Medicigy, 139, 552. 